\title{
Mining, Poverty, and Income Inequality in Central and Eastern European Countries: What Do the Data Tell Us?
}

\author{
Kunofiwa Tsaurai (iD https://orcid.org/0000-0001-8041-1181 \\ Ph.D., Full Professor at the University of South Africa \\ Department of Finance, Risk Management and Banking, Pretoria, South Africa \\ e-mail: kunofiwa.tsaurai@gmail.com
}

\section{Abstract}

The study investigates the effect of mining on both poverty and income inequality in Central and Eastern European countries (CEECs) using econometric estimation methods with panel data spanning from 2009 to 2019. Another objective of this paper was to determine if the complementarity between mining and infrastructural development reduced poverty and or income inequality in CEECs. What triggered the study is the failure of the existing literature to have a common ground regarding the impact of mining on poverty and or income inequality. The existing literature on the subject matter is contradictory, mixed, and divergent; hence, it paves the way for further empirical tests. The study confirmed that the vicious cycle of poverty is relevant in CEECs. According to the dynamic generalized methods of moments (GMM), mining had a significant poverty reduction influence in CEECs. The dynamic GMM and random effects revealed that the complementarity between mining and infrastructural development also enhanced poverty reduction in CEECs. Random effects and pooled OLS shows that mining significantly reduced income inequality in CEECs. However, random effects and the dynamic GMM results indicate that income inequality was significantly reduced by the complementarity between mining and infrastructural development. The authorities in CEECs are therefore urged to implement mining growth and infrastructural development-oriented policies in order to successfully fight off the twin challenges of poverty and income inequality.

Keywords: mining, poverty, income inequality, panel data, CEECs

JEL: I3, I14, I24, L71, N14 


\section{Introduction}

The background of the study, the contribution to the literature, and the organization of the study are the three major components constituting this section.

Background of the study: The positive impact of mining on economic growth is well supported in the literature (Prebisch 1950; Singer 1950; Bhagwati 1958; Cavalcanti, Mohaddes, and Raissi 2011; Tilton 2012; Arezki et al. 2013; Esfahani, Mohaddes, and Pesaran 2014; Kalumbu 2014). They argued that the extraction of mineral resources is labor-intensive and therefore employs a huge number of people, and it has a cascading effect on poverty and inequality reduction in the local communities. Other researchers, such as Harvey et al. (2010; 2017), and Olakojo (2015), noted that mineral extraction boosts economic growth, creates employment, and reduces income inequality and poverty on condition that a favorable environment, such as infrastructural and financial development, exists.

Although there seems to be consensus in the literature on the positive role that mining plays in promoting economic growth, its cascading influence on poverty and income inequality has not been exhaustively investigated. The few empirical researchers who investigated the impact of mining on poverty and income inequality produced results that are divergent, conflicting, mixed, and far from conclusive. Some, such as Hinton (2011), Maier et al. (2014), Fleming and Measham (2015), Ngobese (2015), Loayza and Rigolini (2016), and Barreto et al. (2018), noted that mining managed to reduce income inequality and poverty. Others, namely Fatah (2008), Gregoryan (2013), Adu et al. (2016), Addison, Boly, and Mveyange (2017), and Ankra et al. (2017), observed that mining exacerbates poverty and income inequality.

Others, including Ross (2006), Sudarlan, Indiastuti, and Yusuf (2015), Mancini and Sala (2018), Sincovich et al. (2018), and Zhou (2019), failed to find any meaningful relationship between mining and poverty and or income inequality. They noted that the impact of mining on poverty and income inequality depends on the stage of mining activities. For example, in Australia, Reeson, Measham, and Hosking (2012) noted that poverty and income inequality was low but later went up as mining activity intensified. The lack of consensus both in the theoretical and empirical literature on the impact of mining on poverty and income inequality allows room for further empirical tests.

These empirical studies on the subject matter also suffer from the following methodological limitations. They wrongly assumed that the relationship between mining and poverty/income inequality is linear, ignoring the endogeneity problem normally prevalent in the poverty and income inequality econometric functions. The vicious cycle of poverty was not considered in most of those studies, and none of them focused on CEECs. This means the CEEC story on the mining-poverty/income inequality nexus is still untold to the best of the author's knowledge. The study is important because it will help CEECs to develop mining and infrastructural development policies that will effectively alleviate poverty and income inequality. 
Contribution of the study: This paper contributes to the literature in five ways. Firstly, the use of the dynamic GMM enables the author to consider not only the vicious cycle of poverty and inequality but also the endogeneity problem that normally characterizes both poverty and income inequality functions. Secondly, this study took into account the fact that both poverty and income inequality functions are non-linear, unlike some prior studies. Thirdly, to the best of the author's knowledge, it is the first study to investigate the impact of mining on both poverty and income inequality using CEECs as a unit of analysis. Fourthly, to the best of the author's knowledge, this study is the first to explore the impact of the combination of mining growth and infrastructural development on both poverty and income inequality. Fifthly, this study uses more recent panel data, enabling authorities to make relevant decisions on income inequality and poverty reduction policies.

Structure of the paper: Six additional sections describe the remaining structure of this paper. Section 2 presents the theoretical literature on the impact of mining on poverty and income inequality. Section 3 discusses the influence of mining on poverty and income inequality from an empirical literature point of view. Section 4 describes the effect of infrastructural development on poverty and income inequality. Section 5 outlines the role played by infrastructural development on mining sector growth. Section 6 describes the research methodology, results presentation, and discussion. Section 7 concludes the paper.

\section{Impact of mining on income inequality and poverty - Literature review}

Sudarlan, Indiastuti, and Yusuf (2015) summarized the positive role that mining plays in enhancing poverty and income inequality reduction in four ways. Firstly, it enables developing and poor countries to build a mutually equitable and beneficial mining regime. Secondly, mining helps to improve education as mining companies are generally engaged in corporate social responsibilities that uplift the local communities, consistent with Sudarlan, Indiastuti, and Yusuf (2015, p. 195). Thirdly, mining normally spearheaded by foreign investors transfers technology into the domestic economy, which goes a long way in enhancing innovation and economic growth. Fourthly, mining is in the primary sector of production, is labor-intensive, and hence creates quite a lot of jobs for the poor and the uneducated. This transfers wealth and reduces poverty and income inequality among the societies.

According to Adei, dan Addei, and Kwadjose (2011), the negative impact of mining is divided into three categories:

1. It increases (a) the number of patients suffering from respiratory diseases, (b) land degradation hence negatively impacting on the environment, (c) wildlife habitat loss, (d) air and water pollution as the mining waste is thrown into the rivers and gas emissions poisons the air. 
2. Mining towns promote social ills, such as prostitution, crime, native life changes, and the fight for natural resources among the local people.

3. High mortality rates, which are caused by smoking, low levels of education, and an increased number of years residing in coal mining areas. Sudarlan, Indiastuti, and Yusuf (2015) also confirmed that these negative impacts of mining continue to entrench the people in the poverty cycle and increases the income inequality gap.

Table 1. Empirical literature on the impact of mining on income inequality and poverty

\begin{tabular}{|c|c|c|c|c|}
\hline Author & $\begin{array}{l}\text { Country/ } \\
\text { Countries } \\
\text { of study }\end{array}$ & Period & Methodology & Results \\
\hline $\begin{array}{l}\text { Reeson, } \\
\text { Measham, and } \\
\text { Hosking (2012) }\end{array}$ & $\begin{array}{l}\text { Regional } \\
\text { Australia }\end{array}$ & $1975-2010$ & $\begin{array}{l}\text { Multi-regression } \\
\text { analysis }\end{array}$ & $\begin{array}{l}\text { Income inequality initially } \\
\text { decreased but later went up as } \\
\text { mining activity intensified } \\
\text { in Australia. However, income } \\
\text { inequality was quite low even } \\
\text { at the early stages of mining } \\
\text { activities. }\end{array}$ \\
\hline $\begin{array}{l}\text { Sudarlan, } \\
\text { Indiastuti, and } \\
\text { Yusuf (2015) }\end{array}$ & Indonesia & 2002-2011 & $\begin{array}{l}\text { Panel data } \\
\text { analysis }\end{array}$ & $\begin{array}{l}\text { Mining was found to have had } \\
\text { an insignificant effect on both } \\
\text { income inequality and poverty } \\
\text { in Indonesia. }\end{array}$ \\
\hline $\begin{array}{l}\text { Addison, Boly, } \\
\text { and Mveyange } \\
(2017)\end{array}$ & Africa & 2001-2012 & $\begin{array}{l}\text { Panel data } \\
\text { analysis }\end{array}$ & $\begin{array}{l}\text { When minerals are aggregated, } \\
\text { mining was found to have } \\
\text { increased inequality in Africa. } \\
\text { When minerals were analyzed } \\
\text { as individuals, the impact } \\
\text { of mining on inequality was } \\
\text { found to be mixed. }\end{array}$ \\
\hline $\begin{array}{l}\text { Gregoryan } \\
(2013)\end{array}$ & Armenia & 2000-2008 & $\begin{array}{l}\text { Multi-regression } \\
\text { analysis }\end{array}$ & $\begin{array}{l}\text { Mining was found to have } \\
\text { a high likelihood of increasing } \\
\text { poverty and inequality } \\
\text { in Armenia. }\end{array}$ \\
\hline Ross (2006) & Worldwide & Not applicable & $\begin{array}{l}\text { Literature review } \\
\text { analysis }\end{array}$ & $\begin{array}{l}\text { The pros and cons of mining } \\
\text { on the well-being of the people } \\
\text { where mining is taking place } \\
\text { were explored. Both sides are } \\
\text { compelling. }\end{array}$ \\
\hline $\begin{array}{l}\text { Mancini and } \\
\text { Sala (2018) }\end{array}$ & Worldwide & Not applicable & $\begin{array}{l}\text { Literature review } \\
\text { analysis }\end{array}$ & $\begin{array}{l}\text { The literature on the so- } \\
\text { cio-economic impact of mining } \\
\text { is quite mixed and divergent } \\
\text { globally. }\end{array}$ \\
\hline $\begin{array}{l}\text { Adu et al. } \\
(2016)\end{array}$ & Ghana & $\begin{array}{l}\text { Survey data } \\
\text { for } 1998 / 1999, \\
2005 / 2006, \\
\text { and } \\
2012 / 2013 \\
\text { was used }\end{array}$ & $\begin{array}{l}\text { Descriptive } \\
\text { statistical } \\
\text { analysis }\end{array}$ & $\begin{array}{l}\text { Households at the bottom } \\
\text { of the income distribution were } \\
\text { the ones that heavily expe- } \\
\text { rienced the positive impact } \\
\text { of mining on income inequality }\end{array}$ \\
\hline
\end{tabular}


Mining, Poverty, and Income Inequality in Central and Eastern European Countries...

\begin{tabular}{|c|c|c|c|c|}
\hline Author & $\begin{array}{l}\text { Country/ } \\
\text { Countries } \\
\text { of study }\end{array}$ & Period & Methodology & Results \\
\hline $\begin{array}{l}\text { Sincovich et al. } \\
(2018)\end{array}$ & Australia & $\begin{array}{l}\text { Critical } \\
\text { literature } \\
\text { review }\end{array}$ & $\begin{array}{l}\text { Critical literature } \\
\text { review }\end{array}$ & $\begin{array}{l}\text { The positive and negative im- } \\
\text { pact of mining on income in- } \\
\text { equality, poverty, unemploy- } \\
\text { ment, and economic growth } \\
\text { were outlined in the case } \\
\text { of Australia. }\end{array}$ \\
\hline $\begin{array}{l}\text { Fleming and } \\
\text { Measham } \\
(2015)\end{array}$ & Australia & 2001 and 2011 & $\begin{array}{l}\text { Descriptive } \\
\text { statistics } \\
\text { and multiple } \\
\text { regression } \\
\text { analysis }\end{array}$ & $\begin{array}{l}\text { Income inequality increased } \\
\text { faster in mining regions than } \\
\text { in non-mining regions. The re- } \\
\text { sults, therefore, showed that } \\
\text { mining reduced income ine- } \\
\text { quality. }\end{array}$ \\
\hline Fatah (2008) & $\begin{array}{l}\text { Province } \\
\text { of South } \\
\text { Kalimantan } \\
\text { in Indonesia }\end{array}$ & $\begin{array}{l}\text { Not available } \\
\text { in the abstract } \\
\text { used. }\end{array}$ & $\begin{array}{l}\text { Social } \\
\text { accounting } \\
\text { matrix approach }\end{array}$ & $\begin{array}{l}\text { Coal exploitation had negative } \\
\text { consequences on the local en- } \\
\text { vironment, in the form of land } \\
\text { degradation and water-borne } \\
\text { diseases. This exacerbates pov- } \\
\text { erty and inequality if stringent } \\
\text { environmental rules and poli- } \\
\text { cies are not applied. }\end{array}$ \\
\hline $\begin{array}{l}\text { Loayza and } \\
\text { Rigolini (2016) }\end{array}$ & Peru & $\begin{array}{l}2007 \text { district } \\
\text { survey data }\end{array}$ & $\begin{array}{l}\text { Multi-linear } \\
\text { regression } \\
\text { analysis }\end{array}$ & $\begin{array}{l}\text { Mining districts were found } \\
\text { to have had lower poverty } \\
\text { rates and household consump- } \\
\text { tion per capita in Peru. }\end{array}$ \\
\hline $\begin{array}{l}\text { Maier et al. } \\
(2014)\end{array}$ & $\begin{array}{l}\text { United } \\
\text { States } \\
\text { of America, } \\
\text { China, and } \\
\text { World-Wide }\end{array}$ & 1990-2014 & $\begin{array}{l}\text { Literature review } \\
\text { analysis }\end{array}$ & $\begin{array}{l}\text { Evidence in the literature } \\
\text { explaining the role of mining } \\
\text { in poverty alleviation and } \\
\text { income inequality reduction } \\
\text { in mining regions is evident. }\end{array}$ \\
\hline $\begin{array}{l}\text { Barreto et al. } \\
(2018)\end{array}$ & $\begin{array}{l}\text { Kenya, } \\
\text { Uganda, and } \\
\text { Rwanda }\end{array}$ & $\begin{array}{l}\text { Case study } \\
\text { approach }\end{array}$ & $\begin{array}{l}\text { Case study } \\
\text { methodology }\end{array}$ & $\begin{array}{l}\text { Small scale mining had a } \\
\text { positive impact on livelihood } \\
\text { improvements and poverty } \\
\text { reduction in the three African } \\
\text { countries studied. }\end{array}$ \\
\hline $\begin{array}{l}\text { Ankra et al. } \\
(2017)\end{array}$ & Ghana & $\begin{array}{l}2015 \text { salary } \\
\text { data }\end{array}$ & $\begin{array}{l}\text { Descriptive } \\
\text { statistics }\end{array}$ & $\begin{array}{l}\text { The top ten percent of the min- } \\
\text { ing companies' staff members } \\
\text { were allocated about half of all } \\
\text { the basic salary. This means } \\
\text { that mining increased income } \\
\text { inequality in the case of Ghana. }\end{array}$ \\
\hline Zhou (2019) & $\begin{array}{l}\text { Mongolia's } \\
\text { Oyu Tolgoi } \\
\text { Province }\end{array}$ & $\begin{array}{l}\text { House- } \\
\text { hold-level } \\
\text { census data } \\
(2007-2016)\end{array}$ & $\begin{array}{l}\text { Descriptive } \\
\text { statistics }\end{array}$ & $\begin{array}{l}\text { Health, respiratory diseases, } \\
\text { and unemployment general- } \\
\text { ly went down in mining areas } \\
\text { while school dropout rates, di- } \\
\text { gestive problems, and internet } \\
\text { users went down. }\end{array}$ \\
\hline
\end{tabular}


Table 1. (continued)

\begin{tabular}{|l|l|l|l|l|}
\hline \multicolumn{1}{|c|}{ Author } & $\begin{array}{l}\text { Country/ } \\
\text { Countries } \\
\text { of study }\end{array}$ & \multicolumn{1}{|c|}{ Period } & Methodology & \multicolumn{1}{|c|}{ Results } \\
\hline $\begin{array}{l}\text { Ngobese } \\
\text { (2015) }\end{array}$ & $\begin{array}{l}\text { Amajuba } \\
\text { district } \\
\text { in South } \\
\text { Africa }\end{array}$ & $\begin{array}{l}\text { Interviews } \\
\text { in } 2014\end{array}$ & $\begin{array}{l}\text { Descriptive } \\
\text { statistical } \\
\text { analysis }\end{array}$ & $\begin{array}{l}\text { Mining had a lot of positive } \\
\text { influences in the Amajuba } \\
\text { district. These include reducing } \\
\text { unemployment, enhancing live- } \\
\text { lihoods, and reducing income } \\
\text { inequality. }\end{array}$ \\
\hline Hinton (2011) & Uganda & $\begin{array}{l}\text { Both primary } \\
\text { and secondary } \\
\text { data }\end{array}$ & $\begin{array}{l}\text { Descriptive } \\
\text { statistical } \\
\text { analysis }\end{array}$ & $\begin{array}{l}\text { Artisanal mining played a huge } \\
\text { role in alleviating unemploy- } \\
\text { ment and reducing poverty, } \\
\text { but gender income inequality } \\
\text { remained, with women being } \\
\text { the most disadvantaged. }\end{array}$ \\
\hline
\end{tabular}

Source: author compilation.

\section{The effect of infrastructural development on income inequality and poverty}

According to Estache and Fay (1995), improved infrastructure reduces poverty and income inequality through better water quality, road infrastructure, lower manufacturing costs, and low transportation costs. Infrastructural development was argued to be a key integral component of poverty and income inequality reduction as it links people to important economic activities and helps them gain access to productive opportunities (Jacoby 2000). By contrast, it was noted by Tsaurai and Nyoka (2019), however, that scarce government and private sector resources could have been channeled towards infrastructural development away from small credit provision, whose direct positive influence on poverty and income inequality alleviation is unquestionable. The measure of infrastructural development used in this study is fixed telephone subscriptions (per 100 people).

\section{The role played by infrastructural development on mining growth}

According to the Minerals Council South Africa (2017), better infrastructure development is one of the factors that enhances gold mining in South Africa. Other factors that were singled out by the same report as inhibiting gold mining in South Africa include the cost of extracting the gold, gold price fluctuations, unreliable electricity supply, skills shortages, and a lack of investment in the gold mining sector. Dunning's (1973) eclectic paradigm hypothesis argued that locational advantages, such 
as the level of infrastructural development, market size, and financial development, among others, were the major factors that attract foreign investment to the mining industry in the host country. Denisia (2010, p. 108) also noted that infrastructure development, financial markets, political, and other macro-economic factors are locational advantages that attract foreign capital to not only the mining sector but the whole economy. Moosa (2010) also supported the view that infrastructural development is only one of the factors that foreign investors consider before they are attracted into investing in the mining sector/whole economy of the host country. Considering that the positive impact of foreign direct investment (FDI) on poverty reduction is well supported in the literature, it follows that factors that attract FDI to the mining sector, such as infrastructure development, enhance poverty reduction and income inequality in the local communities. Xongo (2013) also noted that developed infrastructure is one of the preconditions that the country must have for the mining sector to be able to significantly enable poverty reduction.

\section{Research methodology, presentation of the results, and discussion}

Data description, model specification, control variables, panel unit root, and co-integration tests and data analysis.

Nature of data and its description: The data used in this study spans from 2009 to 2019. The dependent variables include income inequality and poverty, while independent variables include infrastructural development, trade openness, information and communication technology (ICT), FDI, human capital development, and financial development. The sources of secondary data include the African Development Bank, World Development Indicators, United Nations Development Programme, the Organization for Economic Cooperation and Development, International Financial Statistics, and the International Monetary Fund. These databases were selected because of their reputation and easy accessibility. The CEECs used in this study include Albania, Croatia, Hungary, Romania, Slovenia, Estonia, Bulgaria, the Czech Republic, Poland, Slovakia, and Lithuania.

General and econometric model specification: Equation 1 is the general model specification for the poverty function, while equation 2 is a general model specification for the income inequality function.

$$
\begin{gathered}
\text { POV }=\mathrm{f}(\mathrm{MIN}, \mathrm{INFR}, \text { OPEN, ICT, FDI, HCD, FIN }) \\
\mathrm{INEQ}=\mathrm{f}(\mathrm{MIN}, \mathrm{INFR}, \mathrm{OPEN}, \mathrm{ICT}, \text { FDI, HCD, FIN })
\end{gathered}
$$

POV, INEQ, MIN, INFR, OPEN, ICT, FDI, HCD, and FIN, respectively, represent poverty, income inequality, mining, infrastructural development, trade openness, 
ICT, FDI, human capital development, and financial development. The choice of the independent variables was, to a larger extent, informed by similar empirical studies such as Fatah (2008), Hinton (2011), Maier et al. (2014), Fleming and Measham (2015), Ngobese (2015), Loayza and Rigolini (2016), Ankra et al. (2017), Barreto et al. (2018), Sincovich et al. (2018), Zhou (2019). The GINI coefficient was used as a measure of income inequality in this study.

Equations 3 and 4 stand for the econometric equations of poverty and income inequality, respectively.

$$
\begin{aligned}
& \operatorname{POV}_{\text {it }}=\beta_{0}+\beta_{1} \mathrm{MIN}_{\text {it }}+\beta_{2} \mathrm{INFR}_{\text {it }}+\beta_{3}\left(\mathrm{MIN}_{\text {it. INFR }}\right)+\beta_{4} \mathrm{X}_{\mathrm{it}}+\text { Eit } \\
& \mathrm{INEQ}_{\mathrm{it}}=\beta_{0}+\beta_{1} \mathrm{MIN}_{\text {it }}+\beta_{2} \mathrm{INFR}_{\mathrm{it}}+\beta_{3}\left(\mathrm{MIN}_{\mathrm{it}} . \mathrm{INFR}_{\mathrm{it}}\right)+\beta_{4} \mathrm{X}_{\mathrm{it}}+\varepsilon i t
\end{aligned}
$$

Table 2. Variable interpretations

\begin{tabular}{|l|l|}
\hline$\beta_{0}$ & Intercept term \\
\hline $\mathrm{t}$ & Time \\
\hline $\mathrm{i}$ & Country \\
\hline$\varepsilon i t$ & Error term \\
\hline$\beta_{1}$ to $\beta_{4}$ & Co-efficient of independent variables \\
\hline $\mathrm{X}_{\text {it }}$ & Independent variable in country $\mathrm{i}$ at time $\mathrm{t}$. \\
\hline POV $_{\mathrm{it}}$ & Poverty in country i at time $\mathrm{t}$ \\
\hline INEQ $_{\mathrm{it}}$ & Income inequality in country $\mathrm{i}$ at time $\mathrm{t}$ \\
\hline MIN $_{\mathrm{it}}$ & Mining development in country i at time $\mathrm{t}$ \\
\hline INFR $_{\text {it }}$ & Infrastructural development in country $\mathrm{i}$ at time $\mathrm{t}$ \\
\hline
\end{tabular}

Source: author compilation.

Equations 3 and 4 are estimated using panel data analysis methods such as fixed effects, pooled ordinary OLS, and random effects, in line with other similar studies by Sudarlan, Indiastuti, and Yusuf (2015) and Addison, Boly, and Mveyange (2017). Consistent with Denisia (2010), infrastructural development plays a critical role in attracting FDI to the mining sector and consequently poverty and income inequality reduction. It is against this background that this study also examined the impact of the complementarity between mining and infrastructural development on poverty and income inequality.

$$
\begin{aligned}
& \mathrm{POV}_{\text {it }}=\beta_{0}+\beta_{1} \mathrm{POV}_{\mathrm{it}-1}+\beta_{2} \mathrm{MIN}_{\text {it }}+\beta_{3} \mathrm{INFR}_{\text {it }}+\beta_{4}\left(\mathrm{MIN}_{\text {it. }} \mathrm{INFR}_{\mathrm{it}}\right)+\beta_{5} \mathrm{X}_{\mathrm{it}}+\text { Eit (5) } \\
& \mathrm{INEQ}_{\mathrm{it}}=\beta_{0}+\beta_{1} \mathrm{INEQ}_{\mathrm{it}-1}+\beta_{2} \mathrm{MIN}_{\mathrm{it}}+\beta_{3} \mathrm{INFR}_{\mathrm{it}}+\beta_{4}\left(\mathrm{MIN}_{\mathrm{it}} . \mathrm{INFR}_{\mathrm{it}}\right)+\beta_{5} \mathrm{X}_{\mathrm{it}}+\text { Eit (6) }
\end{aligned}
$$

The lag of poverty influences poverty (the vicious cycle of poverty), in line with Azher's (1995) theoretical predictions. The control variables that were used, denoted by X, include trade openness, FDI, ICT, financial development, and human capital de- 
velopment. The measure of poverty that was used is the mean mortality rate, while the GINI coefficient is the proxy of income inequality employed in the study. Both equations 5 and 6 were econometrically estimated using the dynamic GMM approach.

Control variables: The variables used as control factors for the income inequality and poverty functions include trade openness, ICT, FDI, human capital, and financial development. The next few paragraphs discuss how each control variable affects poverty and income inequality from a theoretical point of view.

Trade openness, which is proxied by total exports and imports (\% of GDP), positively influences poverty and income inequality reduction, according to Balassa (1978). He argued that trade openness enables domestic firms to access cheaper raw materials and technology worldwide, thereby enhancing their expansion ability, wealth creation, unemployment, poverty, and income inequality reduction.

ICT enhances quality education, research capabilities, innovation skills, and employment creation, thereby enabling people to easily secure well-paying jobs (Richmond and Triplett 2017). They noted that ICT might widen income inequality among people from different social classes. The rich have money to acquire the best ICT gadgets while the poor are further driven into a technology-related abyss. Individuals who use the Internet (\% of population) was used as a measure of ICT.

FDI enables people to acquire skills, enhances human capital development, and creates employment and wealth, thereby reducing poverty and narrowing the income inequality gap (Boakye-Gyasi and Li 2015). In contrast, FDI increases poverty and the income inequality gap because most foreign investors' profit is not used for the benefit of local people but is repatriated back to the home country (Jaumotte, Lall, and Papageorgiou 2013). FDI can have either a positive or negative impact on poverty and income inequality. Net FDI inflows (\% of GDP) is the proxy of FDI used in this study.

Although human capital development reduced poverty, Castello-Climent and Domenech (2014) noted that it was not sufficient to reduce the income inequality gap. According to Johansen (2014), human capital development increases people's competency levels, skills, education, and productivity at the workplace. Such a scenario helps people get a promotion, boosts their income and wealth, and reduces poverty levels and income inequality gaps. The theoretical rationale on the positive relationship running from human capital development towards poverty/income inequality reduction was confirmed by Becker and Chiswick (1966).

Better access to small loans and convenient financial products enables people to get the funding necessary to begin small self-employment projects. The latter provides jobs and income, helping to end poverty and income inequality (World Bank 2001). The development of the financial sector makes it difficult for the poor to access credit because they do not possess collateral security. Meanwhile, the rich get richer because they have assets that can act as collateral security. According to Dhrifi (2013), this increases poverty among the poor and widens the income inequality gap. The impact of financial development on poverty and/or income inequality can be either way. The 
measure of financial development used in this study is the market capitalization of listed domestic companies (\% of GDP). All the variables' data were transformed into natural logarithms before being used further in the study to decisively address spurious results, the possible problem of multicollinearity, and extreme values (Aye and Edoja 2017; Tsaurai 2021).

Panel unit root tests: The use of four panel unit root test methods such as the Levin, Lin, and Chu test (2002), the PP Fisher Chi-Square test; the Augmented Dicky Fuller (ADF) Fisher Chi-Square and Im, Pesaran, and Shin test (2003) to estimate the stability of data used is consistent with other empirical studies such as Aye and Edoja (2017) and Tsaurai (2020).

Table 3. Panel root tests - Individual intercept

\begin{tabular}{|l|c|c|c|c|}
\cline { 2 - 5 } \multicolumn{1}{c|}{} & \multicolumn{5}{c|}{ LLC } & IPS & ADF & PP \\
\cline { 2 - 5 } \multicolumn{1}{c|}{} & $-2.32^{*}$ & $-4.21^{*}$ & 3.12 & 6.98 \\
\hline LIINEQ & $-2.92^{* * *}$ & $-1.18^{* *}$ & $62.18^{* *}$ & $84.913^{* * *}$ \\
\hline LMIN & $-2.65^{* * *}$ & $-3.17^{* * *}$ & $-2.56^{* * *}$ & $-6.17^{* * *}$ \\
\hline LINFR & $-1.56^{* * *}$ & $-0.35^{* * *}$ & $55.82^{* *}$ & $97.12^{* * *}$ \\
\hline LOPEN & $-3.76^{* * *}$ & $-3.87^{* * *}$ & $99.12^{* *}$ & $122.76^{* * *}$ \\
\hline LICT & -0.36 & -.67 & 29.32 & $61.39^{* *}$ \\
\hline LFDI & $-2.54^{* * *}$ & $-1.76^{* * *}$ & $64.23^{* * *}$ & $102.12^{* * *}$ \\
\hline LHCD & $-0.73^{*}$ & $-0.99^{*}$ & $32.18^{* *}$ & $48.27^{* * *}$ \\
\hline LFIN & $-3.14^{* *}$ & $-3.94^{*}$ & $10.21^{* *}$ & $17.37^{* *}$ \\
\hline & & First difference & & $71.32^{*}$ \\
\hline LPOV & $-11.21^{* *}$ & $-19.54^{* *}$ & $56.18^{* *}$ & $278.03^{* * *}$ \\
\hline LINEQ & $-9.42^{* * *}$ & $-7.02^{* * *}$ & $147.25^{* * *}$ & $-16.02^{* * *}$ \\
\hline LMIN & $-5.16^{* * *}$ & $-8.53^{* * *}$ & $-6.18^{* * *}$ & $420.14^{* * *}$ \\
\hline LINFR & $-10.16^{* * *}$ & $-11.34^{* * *}$ & $195.92^{* * *}$ & $642.82^{* * *}$ \\
\hline LOPEN & $-9.32^{* * *}$ & $-10.27^{* * *}$ & $185.93^{* * *}$ & $298.42^{* * *}$ \\
\hline LICT & $-7.37^{* * *}$ & $-8.45^{* * *}$ & $155.12^{* * *}$ & $543.51^{* * *}$ \\
\hline LFDI & $-10.11^{* * *}$ & $-11.23^{* * *}$ & $163.15^{* * *}$ & $18.42^{* * *}$ \\
\hline LHCD & $-6.16^{* * *}$ & $-7.04^{* * *}$ & $116.32^{* * *}$ & $300.26^{* * *}$ \\
\hline LFIN & $-7.23^{* * *}$ & $-8.04^{* *}$ & $91.78^{* * *}$ & 187 \\
\hline
\end{tabular}

Note: LLC, IPS, ADF, and PP stand for Levin, Lin, and Chu; Im, Pesaran, and Shin; ADF Fisher Chi-Square, and PP Fisher Chi-Square tests, respectively. ${ }^{*},{ }^{* *}$ and ${ }^{* * *}$ denote 1\%, 5\% and 10\% levels of significance, respectively.

Source: author's compilation - E-Views figures.

Poverty, income inequality, mining, infrastructural development, trade openness, ICT, FDI, human capital development, and financial development variables were found to be stationary at first difference. The results mean that all the variables used in this study were stable at first difference, allowing the author to proceed to the next stage, which is panel co-integration tests, in line with Odhiambo (2014). 
Panel co-integration tests: The Kao (1999) panel co-integration test was used in this study. Table 4 present the results.

Table 4. Results of Kao co-integration tests

\begin{tabular}{|l|c|}
\hline \multicolumn{1}{|c|}{ Series } & ADF t-statistic \\
\hline POV MIN INFR OPEN ICT FDI HCD FIN & $-2.9121^{* * *}$ \\
\hline INEQ MIN INFR OPEN ICT FDI HCD FIN & $-5.43716^{* * *}$ \\
\hline
\end{tabular}

Source: author compilation.

Consistent with Tembo (2018), a long-run relationship was found to exist in both poverty and income inequality functions. Put differently, a co-integration relationship could not be rejected at the one percent significance level in either the income inequality or poverty functions. The finding enabled the author to proceed to the next stage of analysis.

Main data analysis and interpretation of the results: Four econometric methods were used in this study. These include the dynamic GMM, fixed effects, random effects, and pooled OLS. The proxy of mining in this study is mineral rents (\% of GDP).

Table 5. The poverty function panel results

\begin{tabular}{|l|c|c|c|c|}
\cline { 2 - 5 } \multicolumn{1}{c|}{} & $\begin{array}{c}\text { Dynamic } \\
\text { GMM }\end{array}$ & Fixed effects & $\begin{array}{c}\text { Random } \\
\text { effects }\end{array}$ & Pooled OLS \\
\hline POV $_{\text {it-1 }}$ & $0.1735^{* * *}$ & - & - & - \\
\hline MIN & $-0.1672^{*}$ & -0.0092 & -0.2186 & -0.0372 \\
\hline INFR & $-0.3672^{*}$ & -0.1736 & 0.0267 & 0.1782 \\
\hline MIN.INFR & $-0.1792^{* * *}$ & $-0.0328^{*}$ & 0.1811 & 0.0003 \\
\hline OPEN & $-0.1628^{*}$ & $-0.0327^{*}$ & 0.0163 & $-0.1823^{*}$ \\
\hline ICT & $0.0126^{* * *}$ & $-0.3271^{* *}$ & $-0.1417^{* *}$ & $0.1732^{* *}$ \\
\hline FDI & $-0.1732^{* * *}$ & $-0.0317^{* * *}$ & -0.0327 & -0.1723 \\
\hline HCD & $0.2227^{* *}$ & 0.2371 & 0.1026 & 0.1692 \\
\hline FIN & $-0.1888^{* *}$ & $-0.4555^{* *}$ & $-0.0103^{*}$ & $-0.1932^{* *}$ \\
\hline Adjusted R-squared & 0.67 & 0.62 & 0.55 & 0.58 \\
\hline J-statistic/F-statistic & 148 & 57 & 62 & 43 \\
\hline Prob(J-statistic/F-statistic & 0.00 & 0.00 & 0.00 & 0.00 \\
\hline
\end{tabular}

***, ${ }^{* *}$ and ${ }^{*}$ denote $1 \%, 5 \%$ and $10 \%$ levels of significance, respectively.

Source: author's compilation from E-Views.

Using the mean mortality rate as a measure of poverty, the lag of poverty was found to have had a significant positive impact on poverty. In other words, the mortality rate was positively influenced by its own lag, in line with Azher's (1995) vicious cycle of poverty argument. The dynamic GMM approach produced results that show that mining had a significant negative impact on the mean mortality rate while fixed effects, pooled OLS, and random effects show a non-significant relationship with the 
mean mining mortality rate. In general, these results indicate that mining reduced poverty in CEECs across all the four-panel methods used.

Infrastructural development's influence on mean mortality was found to be negative and significant under the dynamic GMM, yet fixed effects show that mining had an insignificant negative effect on mean mortality. These results show that infrastructural development reduced poverty in CEECs, which is consistent with Estache and Fay (1995). The positive non-significant impact of infrastructural development on mean mortality was observed under the random effects and pooled OLS, in line with Tsaurai and Nyoka (2019), whose study argued that that scarce government and private sector resources channeled towards infrastructural development away from small credit provision exacerbates poverty.

The impact of the complementarity between mining and infrastructural development on mean mortality was found to be negative but significant under both the fixed effects and dynamic GMM methodologies. This means that the combination of mining and infrastructural development significantly reduced poverty in CEECs, a finding that is consistent with Xongo (2013), whose study found that developed and better infrastructure is one of the preconditions that a country must have for the mining sector to be able to significantly reduce poverty. However, a non-significant positive relationship running from the complementarity between mining and infrastructural development towards mean mortality was observed under the pooled OLS and the random effects. These results mean that the interaction variable exacerbates poverty, contradicting the available literature that states that infrastructural development is one of the locational advantages of foreign investment in the mining sector (Moosa 2010).

Under the dynamic GMM, fixed effects, and pooled OLS, the influence of trade openness on mean mortality was found to be negative but significant. Put differently, trade openness contributed to a reduction in poverty in the CEECs, in line with Balassa's (1978) argument earlier in the sub-section on control variables. By contrast, the random effects produced results that show a non-significant relationship running from trade openness towards mean mortality. This means that trade openness generally increased poverty under the random effects, a finding which contradicts the available literature.

ICT was found to have a significant positive impact on mean mortality under both the pooled OLS and the dynamic GMM approaches, in line with Richmond and Triplett (2017), whose study noted that ICT may increase poverty and widen income inequality among people from different social classes. Fixed and random effects, however, noted that ICT's impact on mean mortality in CEECs was negative but significant. On the other hand, the results resonate with Richmond and Triplett (2017), who stated that ICT enhances quality education, research capabilities, innovation skills, and employment creation, thereby enabling people to easily secure well-paying jobs.

FDI had a significant negative impact on mean mortality under both the dynamic GMM and fixed effects, and a non-significant negative effect on mean mortality under the random and pooled OLS. These results are like those obtained under the income 
inequality function (see results in Table 6). They generally mean that FDI reduced poverty, which is consistent with Boakye-Gyasi and Li's (2015) theoretical rationale that FDI enables people to get skills, enhances human capital development, and creates employment and wealth, thereby reducing poverty and narrowing the income inequality gap.

A significant positive relationship running from human capital development towards mean mortality was observed under the dynamic GMM approach, while fixed effects, random effects, and pooled OLS show that human capital development had a non-significant positive effect on mean mortality. These results are like the findings produced under the income inequality function (see Table 6) across all four econometric estimation methods. They contradict the available literature on the human capital development-poverty/income inequality nexus propagated by Becker and Chiswick (1966), Castello-Climent and Domenech (2014), and Johansen (2014).

Financial development had a significant negative effect on mean mortality across all four econometric estimation methods. Apart from the random effects, the other three panel data analysis methods (dynamic GMM, pooled OLS, fixed effects) produced results that show that financial management's influence on mean mortality was negative but significant. This means that financial management reduced poverty and income inequality in CEECs, consistent with the World Bank (2001), which stated that better access to small loans and convenient financial products enables people to get the funding necessary to begin small self-employment projects.

Table 6. The income inequality function panel results

\begin{tabular}{|lc|c|c|c|}
\cline { 2 - 5 } \multicolumn{1}{l|}{} & $\begin{array}{c}\text { Dynamic } \\
\text { GMM }\end{array}$ & Fixed effects & $\begin{array}{c}\text { Random } \\
\text { effects }\end{array}$ & Pooled OLS \\
\hline INEQ & $0.4823^{* * *}$ & - & - & - \\
\hline MIN & 0.3288 & 0.1835 & $-0.1218^{*}$ & $-0.1997^{* *}$ \\
\hline INFR & -0.6931 & $-0.0227^{*}$ & $0.1743^{*}$ & 0.1634 \\
\hline MIN.INFR & $-0.6372^{* * *}$ & -0.2871 & $-0.1835^{* *}$ & 0.0092 \\
\hline OPEN & 0.0665 & $-0.2273^{*}$ & -0.0452 & $0.4521^{*}$ \\
\hline ICT & 0.0438 & $0.4573^{* *}$ & $-0.2763^{* *}$ & 0.0435 \\
\hline FDI & $-0.5563^{* * *}$ & $-0.4009^{* * *}$ & -0.5764 & -0.4111 \\
\hline HCD & 0.0065 & 0.4521 & 0.58976 & 0.6548 \\
\hline FIN & $-0.5466^{* *}$ & $-0.5491^{* *}$ & -0.1632 & $-0.3318^{* *}$ \\
\hline Adjusted R-squared & 0.56 & 0.59 & 0.65 & 0.68 \\
\hline J-statistic/F-statistic & 251 & 89 & 71 & 54 \\
\hline Prob(J-statistic/F-statistic) & 0.00 & 0.00 & 0.00 & 0.00 \\
\hline
\end{tabular}

***, ${ }^{* *}$ and ${ }^{*}$ denote $1 \%, 5 \%$ and $10 \%$ levels of significance, respectively.

Source: author's compilation from E-Views.

The GINI coefficient is the measure of income inequality that was used in this study. Consistent with Azher (1995), previous income inequality exacerbated income inequality (measured the GINI ratio) in the CEECs. A non-significant positive relation- 
ship running from mining towards income inequality (GINI ratio) was observed under the dynamic GMM and fixed effects, in line with Adei, dan Addei, and Kwadjose (2011), whose study laid bare the negative impact of mining activities on local people. Random effects and pooled OLS show that mining had a significant negative influence on the GINI ratio, in line with Sudarlan, Indiastuti, and Yusuf (2015, p. 195), whose study observed that mining helps to reduce income inequality.

The dynamic GMM showed that infrastructural development had a non-significant influence on the GINI ratio while fixed effects' impact on the GINI ratio was negative and significant. The results show that infrastructural development reduced income inequality in CEECs, which is consistent with Estache and Fay (1995), whose study noted that infrastructure reduces poverty and income inequality through better water quality, road infrastructure, lower manufacturing costs, and low transportation costs. By contrast, both random effects and pooled OLS shows that infrastructural development increased income inequality in CEECs, in support of Tsaurai and Nyoka (2019). Only the dynamic GMM and random effects show that the complementarity between mining and infrastructural development reduced income inequality in CEECs, in line with Dunning (1973), Denisia (2010), Moosa's (2010), and Xongo (2013), theoretical rationales.

The impact of trade openness on income inequality is mixed. Dynamic GMM showed that trade openness had a non-significant positive influence on the GINI ratio, while a significant positive relationship running from trade openness towards the GINI ratio was observed under the pooled OLS. This means that generally, trade openness increased income inequality, in contrast to Balassa (1978). However, fixed and random effects show that trade openness helped reduce income inequality in CEECs, in line with the available literature. The results on the impact of ICT on income inequality are mixed. Dynamic GMM, fixed effects, and pooled OLS show that ICT increased income inequality while the random effects indicate that income inequality reduction was spearheaded by ICT.

\section{Conclusions}

The study aimed to investigate the effect of mining on both poverty and income inequality in CEECs using econometric estimation methods with panel data spanning from 2009 to 2019. Another objective of this paper was to determine if the complementarity between mining and infrastructural development reduced poverty and/ or income inequality in CEECs. What triggered the study is the failure of the existing literature to have a common ground regarding the impact of mining on poverty and or income inequality. The existing literature on the subject matter is contradictory, mixed, and divergent; hence, it paves the way for further empirical tests. The study confirmed that the vicious cycle of poverty is relevant in CEECs. 
According to the dynamic GMM, mining had a significant poverty reduction influence in CEECs. The dynamic GMM and random effects revealed that the complementarity between mining and infrastructural development also enhanced poverty reduction in CEECs. Random effects and pooled OLS shows that mining significantly reduced income inequality in CEECs. However, random effects and the dynamic GMM results indicate that income inequality was significantly reduced by the complementarity between mining and infrastructural development in CEECs. The authorities in CEECs are therefore urged to implement mining growth and infrastructural development-oriented policies to successfully fight off the twin challenges of poverty and income inequality. Further research should investigate the existence of threshold levels of mining growth, and infrastructural development that must be reached before significant poverty and income inequality reduction can happen.

\section{References}

Addison, T., Boly, A., Mveyange, A. (2017), The impact of mining on spatial inequality: Recent evidence from Africa, "United Nations University WIDER Working Paper", No. 2017/13, https://doi.org/10.35188/UNU-WIDER/2017/237-3

Adei, D.I., Addei, H.A. dan, Kwadjose, R. (2011), A Study of Effects Mining Activities on the Health Status of People: A Case Study, "Research Journal of Applied Sciences, Engineering and Technology", 3 (2), pp. 99-104.

Adu, G., Amuakwa-Mensah, F., Marbuah, G., Mensah, J.T. (2016), Effect of gold mining on income distribution in Ghana, "FAERE Working Paper Series", No. 23/2016.

Ankra, P.W., Gbana, A., Adjei-Danso, E., Arthur, A., Agyapong, S. (2017), Evidence of the income inequality in the mining industry of Ghana, "Journal of Economics and Development Studies”, 5 (1), pp. 79-90, https://doi.org/10.15640/jeds.v5n1a8

Arezki, R., Hadri, K., Loungani, P., Rao, Y. (2013), Testing the Prebisch-Singer hypothesis since 1650: Evidence from panel techniques that allow for multiple breaks, "International Monetary Fund Working Paper", No. 13/180, pp. 1-37, https://doi.org /10.5089/9781484341155.001

Aye, G.C., Edoja, P.E. (2017), Effect of economic growth on $\mathrm{CO}_{2}$ emission in developing countries: Evidence from a dynamic panel threshold model, "Cogent Economics and Finance”, 5 (1), pp. 1-22, https://doi.org/10.1080/23322039.2017.1379239

Azher, B.A. (1995), Rural savings: Their magnitude, determinants and mobilization, "Pakistan Development Review", 34 (4), pp. 779-786, https://doi.org/10.30541/v3 4i4IIpp.779-788

Balassa, B. (1978), Exports and economic growth: further evidence, "Journal of Development Economics”, 5 (2), pp. 181-189, https://doi.org/10.1016/0304-3878(78)90006-8

Barreto, M.L., Schein, P., Hinton, J., Hruschka, F. (2018), The impact of small-scale mining operations on economies and livelihoods in low to medium income countries, East Africa Research Fund, https://assets.publishing.service.gov.uk/media/5a3929 b640f0b649cfaf86ce/Pact__DFID_EARF_Overarching_Synthesis_Jan2018VF.pdf (accessed: 9.07.2021). 
Becker, G.S., Chiswick, B.R. (1966), Education and the distribution of earnings, "American Economic Review", 56 (1/2), pp. 358-369.

Bhagwati, J. (1958), Immiserizing growth: A geometrical note, "Review of Economic Studies”, 25 (3), pp. 201-205, https://doi.org/10.2307/2295990

Boakye-Gyasi, K., Li, Y. (2015), The impact of Chinese FDI on employment generation in the building and construction sector of Ghana, "Eurasian Journal of Social Sciences”, 3 (2), pp. 1-15, https://doi.org/10.15604/ejss.2015.03.02.001

Castello-Climent, A., Domenech, R. (2014), Human capital and income inequality: Some facts and some puzzles, BBVA, "Working Paper", No. 12/28.

Cavalcanti, T.V.D.V., Mohaddes, K., Raissi, M. (2011), Growth, development and natural resources: New evidence using a heterogeneous panel analysis, "Quarterly Review of Economics and Finance", 51 (4), pp. 305-318, https://doi.org/10.2139/ssrn.1505311

Denisia, V. (2010), Foreign direct investment theories: An overview of the main theories, "European Journal of Interdisciplinary Studies", 2 (2), pp. 104-110.

Dhrifi, A. (2013), Financial development and the growth-inequality-poverty triangle: A comparative study between developed and developing countries, "International Journal of Economics, Finance and Management”, 2 (7), pp. 472-481.

Dunning, J.H. (1973), The determinants of international production, "Oxford Economic Papers”, 25 (3), pp. 289-336, https://doi.org/10.1093/oxfordjournals.oep.a041261

Esfahani, H.S., Mohaddes, K., Pesaran, M.H. (2014), An empirical growth model for major oil exporters, "Journal of Applied Econometrics", 29 (1), pp. 1-21, https://doi .org/10.1002/jae.2294

Estache, A., Fay, M. (1995), Regional growth in Argentina and Brazil: Determinants and policy options, The World Bank, Mimeo, Washington.

Fatah, L. (2008), The impacts of coal mining on the economy and environment of South Kalimantan Province, Indonesia, "Asean Economic Bulletin”, 25 (1), pp. 85-98, https://idl-bnc-idrc.dspacedirect.org/bitstream/handle/10625/45001/IDL-45001 .pdf? sequence $=1 \&$ is Allowed $=y$ (accessed: 17.09.2020).

Fleming, D.A., Measham, T.G. (2015), Income inequality across Australian regions during the mining boom, 2001-2011, “Australian Geographer”, 46 (2), pp. 203-216, https://doi.org/10.1080/00049182.2015.1020596

Gregoryan, A. (2013), The impact of mining sector on growth, inequality and poverty: Evidence from Armenia, American University of Armenia, Yerevan.

Harvey, D.I., Kellard, N.M., Madsen, J.B., Wohar, M.E. (2010), The Prebisch-Singer hypothesis: Four centuries of evidence, "Review of Economics and Statistics", 92 (2), pp. 367-377, https://doi.org/10.1162/rest.2010.12184

Harvey, D.I., Kellard, N.M., Madsen, J.B., Wohar, M.E. (2017), Long run commodity prices, economic growth and interest rates: $17^{\text {th }}$ century to the present day, "World Development”, 89 (January), pp. 57-70, https://doi.org/10.1016/j.worlddev.2016.07.012

Hinton, J.J. (2011), Gender differentiated impacts of artisanal mining: Engendering pathways out of poverty: A case study in Katwe Kabatooro town council, Unpublished Doctoral Thesis, The University of British Columbia, Uganda.

Im, K.S., Pesaran, M.H., Shin, Y. (2003), Testing unit roots in heterogeneous panels, "Journal of Econometrics", 115 (1), pp. 53-74, https://doi.org/10.1016/S0304-4076 (03)00092-7 
Jacoby, H. (2000), Access to rural markets and the benefits of rural roads, "Economic Journal", 110 (465), pp. 713-737, https://doi.org/10.1111/1468-0297.00562

Jaumotte, F., Lall, S., Papageorgiou, C. (2013), Rising income inequality: Technology or trade and financial globalization?, "IMF Economic Review", 61 (2), pp. 271-309, https://doi.org/10.1057/imfer.2013.7

Johansen, A.L. (2014), The effect of human capital on income inequality: An econometric analysis, Unpublished Master's Thesis - Department of Applied Economics, Copenhagen Business School, Copenhagen.

Kalumbu, S. (2014), Terms of trade and economic growth in Namibia, "An Online International Research Journal”, 1 (3), pp. 90-101.

Kao, C. (1999), Spurious regression and residual-based tests for co-integration in panel data, "Journal of Econometrics", 90 (1), pp. 247-259, https://doi.org/10.1016/S03 04-4076(98)00023-2

Levin, A., Lin, C.F., Chu, C.S.J. (2002), Unit root tests in panel data: Asymptotic and finite-sample properties, "Journal of Econometrics", 108 (1), pp. 1-24, https://doi.org /10.1016/S0304-4076(01)00098-7

Loayza, N., Rigolini, J. (2016), The local impact of mining on poverty and inequality: Evidence from commodity boom in Peru, "World Development", 84, pp. 1-10, https:// doi.org/10.1016/j.worlddev.2016.03.005

Maier, R.M., Diaz-Barriga, F., Field, J.A., Hopkins, J., Klein B., Poulton, M.M. (2014), Socially responsible mining: The relationship between mining and poverty, human health and the environment, "Review of the Environment Health", 29 (1), pp. 83-89, https://doi.org/10.1515/reveh-2014-0022

Mancini, L., Sala, S. (2018), Socio impact assessment in the mining sector: Review and comparison of indicators frameworks, "Resources Policy", 57, pp. 98-111, https://doi .org/10.1016/j.resourpol.2018.02.002

Minerals Council South Africa (2017), Factors hindering gold mining in South Africa, https://www.miningforschools.co.za/lets-explore/gold/factors-that-favour-or-hin der-gold-mining (accessed: 9.07.2021).

Moosa, I.A. (2010), International finance: An analytical approach, $3^{\text {rd }}$ edition, McGraw Hill Australia Pty Ltd., Sydney.

Ngobese, S.S. (2015), Examining the socio-economic impact of mining on the livelihoods of Amajuba District mining communities, Unpublished Master of Commerce Degree, University of KwaZulu Natal, Durban.

Odhiambo, N.M. (2014), Financial systems and economic growth in South Africa: A dynamic complementarity test, "International Review of Applied Economics", 28 (1), pp. 83-101, https://doi.org/10.1080/02692171.2013.828681

Olakojo, S.A. (2015), Export commodity prices and long run growth of primary commodities based African economies. Centre for the Study of the Economies of Africa, "Working Paper WPS/15/02".

Prebisch, R. (1950), The economic development of Latin America and its principal problems, "Economic Bulletin for Latin America", 7 (1), pp. 1-22.

Reeson, A.F., Measham, T.G., Hosking, K. (2012), Mining activity, income inequality and gender in regional Australia, "Agricultural and Resource Economics", 56 (2), pp. 302-313, https://doi.org/10.1111/j.1467-8489.2012.00578.x 
Richmond, K., Triplett, R. (2017), ICT and income inequality: A cross-national perspective, "International Journal of Applied Economics", 32 (2), pp. 1-20, https://doi.org /10.1080/02692171.2017.1338677

Ross, M. (2006), How can mineral rich reduce inequality?, "Initiative for Policy Dialogue Working Paper Series", September.

Sincovich, A., Gregory, T., Wilson, A., Bronkman, S. (2018), The social impacts of mining on local communities in Australia, "Rural Society", 27 (1), pp. 18-34, https://doi .org/10.1080/10371656.2018.1443725

Singer, H. (1950), Comments to the terms of trade and economic development, "Review of Economics and Statistics", 40 (1), pp. 84-89, https://doi.org/10.2307/1926250

Sudarlan, K., Indiastuti, R., Yusuf, A.A. (2015), Impact of mining sector to poverty and income inequality in Indonesia: A panel data analysis, "International Journal of Scientific and Technology Research", 4 (6), pp. 195-200.

Tembo, J. (2018), Regional financial integration and its impact on financial sector development: The case of Southern Africa, Unpublished Doctoral Thesis, University of South Africa, Pretoria.

Tilton, J. (2012), The terms of trade debate and the policy implications for primary product producers, "Division of Economics and Business Working Paper Series", No. 2012-11.

Tsaurai, K. (2020), Foreign direct investment and human capital development in Africa, "EuroEconomica", 39 (3), pp. 11-23.

Tsaurai, K. (2021), Economic growth-financial development-poverty nexus in emerging markets, "International Journal of Services, Economics and Management", 12 (1), pp. 93-108, https://doi.org/10.1504/IJSEM.2021.113468

Tsaurai. K., Nyoka, C. (2019), Financial development-income inequality nexus in South Eastern European countries; Does the relationship vary with the level of inflation?, "International Journal of Services, Economics and Management", 10 (2), pp. 110125, https://doi.org/10.1504/IJSEM.2019.100921

World Bank (2001), World Development Report 2000, Oxford University Press, New York.

Xongo, N. (2013), The impact of mining on infrastructure development and poverty reduction in mining communities, Unpublished Master's Thesis, Nelson Mandela Metropolitan University, Summerstrand.

Zhou, A. (2019), Oyu Tolgoi: Impact of mining on economic outcomes in Mongolia, Unpublished Bachelor of Arts Degree in Economics, Harvard College, Cambridge. 


\section{Górnictwo, ubóstwo i nierówności dochodowe w krajach Europy Środkowej i Wschodniej: co mówią dane?}

Artykuł prezentuje wyniki badania wpływu górnictwa zarówno na ubóstwo, jak i na nierówności dochodowe w krajach Europy Środkowej i Wschodniej, przy użyciu metod estymacji ekonometrycznej z wykorzystaniem danych panelowych z lat 20092019. Drugim celem tego artykułu było ustalenie, czy komplementarność górnictwa i rozwoju infrastruktury zmniejsza ubóstwo lub nierówności dochodowe w krajach Europy Środkowej i Wschodniej. Impulsem do podjęcia badań był brak w istniejącej literaturze przedmiotu wspólnego stanowiska w kwestii wpływu górnictwa na ubóstwo i nierówności dochodowe. Istniejąca literatura na ten temat jest sprzeczna, niejednoznaczna i rozbieżna, dlatego też otwiera drogę do dalszych badań empirycznych. Badanie potwierdziło, że błędne koło ubóstwa występuje w krajach Europy Środkowej i Wschodniej. Zgodnie z dynamicznymi uogólnionymi metodami momentów (GMM), górnictwo miało znaczący wpływ na redukcję ubóstwa w krajach Europy Środkowej i Wschodniej. Dynamiczna metoda momentów GMM i efektów losowych ujawniły, że komplementarność górnictwa i rozwoju infrastruktury również przyczyniła się do zmniejszenia ubóstwa w krajach Europy Środkowej i Wschodniej. Metoda efektów losowych i metoda pooled OLS pokazują, że górnictwo znacząco zmniejszyło nierówności dochodowe w krajach Europy Środkowej i Wschodniej. Jednak wyniki uzyskane przy zastosowaniu metody efektów losowych i dynamicznej metody GMM wskazują, że nierówności dochodowe zostały znacznie zmniejszone dzięki komplementarności górnictwa i rozwoju infrastruktury. W związku z tym zachęca się władze krajów Europy Środkowej i Wschodniej do wdrażania polityk ukierunkowanych na rozwój górnictwa i rozwój infrastruktury, aby skutecznie walczyć z podwójnymi wyzwaniami związanymi z ubóstwem i nierównościami dochodowymi.

Słowa kluczowe: górnictwo, ubóstwo, nierówności dochodowe, dane panelowe, kraje Europy Środkowej i Wschodniej 